No. XII

LIST OF PUBLICATIONS BASED ON RESULTS OBTAINED AT THE BIOLOGICAL STATIONS OF CANADA, 1901-1921.

COMPILED BY

A. G. HUNTSMAN AND C. M. FRASER 



\title{
List of Publications based on Results obtained at the Biological Stations of Canada, I901-rg2I.
}

\author{
Compiled by A. G. Huntsman and C. M. Fraser
}

Bailey, L. W. 1910. The Marine and Estuarine Diatoms of the New Brunswick coasts. Bull. Nat. Hist. Soc., New Brunswick, No. XXVIII., pp. 219-239, pl. 1, 2.

1912. The fresh water Diatoms and Diatomaceous Earths of New Brunswick. Bull. Nat. Hist.' Soc., New Brunswick, No. XXIX., pp. 291-320.

1912. Diatoms of New Brunswick. III. Forms from the North Shore. Bull. Nat. Hist. Soc., New Brunswick, Vol. VI., No. 30, pp. 387-417.

1912. Some recent Diatoms, freshwater and marine, from the vicinity of the Atlantic Biological Station, St. Andrews, N.B. Contr. Canadian Biol., 1906-10. pp. 243-264, pl. 25, 26.

1913. The Diatoms of New Brunswick and Prince Edward Island. Trans. Roy. Soc. Canada, Ser. III., -Vol. VII., pp. 57-76.

1915. The plankton Diatoms of the Bay of Fundy. Contr. Canadian Biol., 1911-14, Fasc. I., pp. 11-23, pl. 1-3.

1917. Notes on the Phyto-plankton of the Bay of Fundy and Passamaquoddy Bay. Contr. Canadian Biol., 1915-16, pp. 93-107.

1917. The Geological features of the St. Croix river and Passamaquaddy Bay. Contr. Canadian Biol., 1915-16, pp. 109-112.

1917. The marine life of our coasts. Bull. Nat. Hist. Soc., New Brunswick, No. XXXII. '(Vol. VII.), 1917, pp. 99-104.

BaIley, L. W. and MACKAY, A. H. 1916. Diatoms from the eastern coast of Vancouver Island. Trans. Roy. Soc, Canada, Third Series, Vol. IX., Section IV., pp. 141-174.

1921. The Diatoms of Canada. Contr. Canadian Biol., 1918-20, pp. 15-1 124 .

BARTSCH, P. 1921. A new classification of shipworms and descriptions of -some new wood boring mollusks. Proc. Biol. Soc., Washington, Vol. XXXIV., pp. 25-32. Xylophaga washingtoni from Departure Bay.

1921. New marine mollusks from the west coast of America. Ibid., pp. $35-40$.

Odostomis cumshewaensis, Cerithiopsis fraseri, C. signa. Alvania burrardensis and Vitrinella columbiana from British Columbia.

BEAN, B. A. and WEED, A. C. 1919. Notes on a collection of fishes from Vancouver Island, British Columbia. Trans. Roy. Sơc. Canada, Series III., Vol. XIII., Sect. V., pp. 69-83. 
Bensley, B. A. 1901. Report on the sardine industry in relation to the Canadian herring fisheries. Contr. Canadian Biol., 1901, pp. 59-62.

1915. The Fishes of Georgian Bay. Contr. Canadian Biol., 1911-1914, Fasc. II., pp. 1-51.

Berkeley, C. 1919. A study of marine Bacteria, Straits of Georgia, B.C. Trans. Roy. Soc. Canada, Third Series, Vol. XIII., Sect. V., pp. 15-25.

1920. Pentose contents of some tissues of marine animals. Journ. Biological Chemistry, Vol. XLI., No. 3, pp. liv.-lv.

1920. Pentosan- and Methylpentosan-splitting enzymes of Macrocystis pyrifera. Journ. Biological Chemistry, Vol. XLI., No. 3, pp. LVI.-LVII.

1921. Pentose mononucleotides of the pancreas of the dogfish (Squalus sucklii). Journ. Biological Chemistry. Vol. XLV., No. 2, pp. 263-275.

1921. Anaerobic respiration in some pelecypod molluscs. The relation of anaerobic respiration to glycogen. Journ. Biological Chemistry, Vol. XLVI., No. 3, pp. 579-598.

Bigelow, H. B. 1916. Halimedusa, a new genus of Anthomedusae. Trans. Roy. Soc. Canada, Vol. X., pp. 91-95.

Description of Halimedusa typus, n.g., n.s. from the coast of Vancouver Island.

Bissonette, T. H. 1915. List of Georgian Bay Fleshy Fungi and Myxomycetes. Contr. Canadian Biol., 1911-1914, Fasc. II., pp. 213-218.

Bjerkan, Paul. 1919. Results of the hydrographical observations made by Dr. Johan Hjort in the Canadian Atlantic waters during the year 1915. Can, Fish. Exp., 1914-15, Gulf of St. Lawrence, pp. 349403, PI. I., 2.

Burwash, E. M. 1912. The Geological Environment of the British Columbia Biological Station at Departure Bay, B.C. Contr. Canadian Biol., 1906-1910, pp. 295-305.

Cameron, A. T. 1914. The distribution of Iodine in plant and animal tissues. I. Journ. Biological Chemistry, Vol. XVIII., pp. 335-380.

Material collected at Pacific Coast Station.

1914. The distribution of Iodine in plant and animal tissues. Trans. Roy. Soc. Canada, Third Series, Vol. VIII., Section IV., pp. 7-10.

Material collected at Pacific Coast Station.

1915. The distribution of Iodine in plant and animal tissues. II. Journ. Biological Chemistry, Vol. XXIII., pp. 1-39. Baltimore.

Material collected at the Pacific Coast Station.

1915. The iodine content of the marine flora and fauna in the neighbourhood of Nanaimo, Vancouver Island, B.C. Contr. Canadian Biol., 1911-1914, Fasc. I., pp. 52-68.

1915. The commerical value of the kelp beds of British Columbia. Contr. Canadian Biol., 1914-1915, pp. 25-40. 
Cameron; A. T. 1915. The water and iodine contents of some Pacific coast kelps. Ibid., pp. 169-173.

Cameron, A. T. and Fraser, C. M. 1915. Variations in density and temperature in the coastal waters of British Columbia. Ibid., pp. 133-144.

Cameron, A. T. and Vincent, S. 1915. Note on an enlarged thyroid occurring in an Elasmobranch fish (Squalus sucklii). Journ. Med. Research, Vol. XXXII., pp. 251-256.

Obtained at Pacific station.

Clemens, W. A. 1915. Rearing Experiments and Ecology of Georgian Bay Ephemerida. Contr. Canadian Biol., 1911-1914, Fasc. II., pp. 113-128, 2 pls.

1915. Life-histories of Georgian Bay Ephemeridæ. Observations on Heptagenia and Breeding Experiments. . Contr. Canadian Biol., 1911-1914, Fasc. II., pp. 131-143, 4 pls.

1920. Histories of New Food Fishes. IV. The Muttonfish. Bull. Biol. Board of Canada, No. 4, pp. 1-12.

Clemens, W. A. and L. S. 1921. A contribution to the biology of the mutton fish (Zoarces anguillaris). Contr. Canadian Biol., 1918-20. (1921), pp. 69-83, 1 pl.

Collins, F. S. 1913. The marine algae of Vancouver Island. Victoria Memorial Museum, Bulletin I., Geological Survey of Canada, pp. 95-137.

Collip, J. B. 1920. The alkali reserve of marine fish and invertebrates. The excretion of carbon dioxide. Journ. Biological Chemistry, Vol. XLIV., No. 2, pp. 329-344.

1920. Studies on Molluscan coelomic fluid. Anaerobic respiration in Mya arenaria. Ibid., Vol. XLV., No. 1, pp. 23-47.

Connolly, C. J. 1920. History of New Food Fishes. III. The Angler. Bull. Biol. Board of Canada, No. 3, pp. 1-17.

Cooper, A. R. 1914. A new Cestode from. Amia Calva L. Trans. Roy. Canadian Inst., Vol. X., pp. 81-119, 3 pls.

1914. On the Systematic Position of Haplobothrium globuliforme Cooper. Trans. Roy. Soc. Canada, Ser. III., Vol. VIII., pp. 1-3.

1915. Trematodes from Marine and Fresh-water Fishes, including one species of Ectoparasitic Turbellarian. Trans. Roy. Soc. Canada, Ser. III., Vol. 9, pp. 181-205, 3 pls.

1915. A morphological study of Bothriocephalid Cestodes from Fishes. Journ. Parasitology, Vol. 4, pp. 33-39, 2 pls.

1915. North American Pseudophyllidean Cestodes from Fishes. III. Illinois Biol. Monographs, 4 (No. 4), pp. 289-541, 13 pls.

1915. Contributions to the Life-history of Proteocephalus ambloplitis Leidy, a parasite of the Black Bass. Contr. Canadian Biol., 19111914, Fasc. II., pp. 177-194, 3 pls. 
Copeland, G. G. 1912. On the temperatures and densities of Passamaquoddy Bay waters and environs, with notes on allied subjects and the bearings of the same on the oyster industry. Contr. Canadian Biol., 1906-1910, pp. 281-294, pl. 36-37.

Connish, Geo. A. 1907. Report on the Marine Polyzoa of Canso, N.S. Contr. Canadian Biol., 1902-05 (1907), pp. 75-80.

1907. Notes on the fishes of Canso. Ibid., pp. 81-90.

1912. Notes on the Fauna of Tignish, Prince Edward Island. Contr. Canadian Biol., 1906-10, pp. 79-81.

Cox, Philip. 1916. On a supposed disease of Quahaugs from New Brunswick. Contr. Canadian Biol., 1914-15, pp. 73-79.

1916. Investigation of a disease of herring (Clupea harengus) in the Gulf of St. Lawrence. Contr. Canadian Biol., 1914-15, pp. 81-84, pls. 8 and 9 .

1916. Are migrating eels deterred by a range of lights? Contr. Canadian Biol., 1914-15, pp. 115-118.

1920. Histories of New Food Fishes. II. The Lumpfish. Bull. Biol. Board Canada, No. 2, pp. 1-28.

1921. List of fishes collected in .1917 off the Cape Breton coast and the Magdalen Islands. Contr. Canadian Biol., 1918-20 (1921), pp. 109-114.

Craigie, D. Horne. 1916. Life History of the Hake (Urophycis chuss). Contr. Canadian Biol., 1914-15 (1916), pp. 87-94.

1916. Hydrographic Investigations in the St. Croix River and Passamaquoddy Bay. Contr. Canadian Biol., 1914-15 (1916), pp. 151-161.

1916. Hydrographic section of the Bay of Fundy in 1914. Contr. Canadian Biol., 1914-15, pp. 163-173.

Craigie, E. H. and Chase, W. H. 1918. Further Hydrographic Investigations in the Bay of Fundy. Contr. Canadian Biol., 1917-18, pp. 125-147.

Currie, Mary E. 1918. Exuviation and variation of plankton copepods, with special reference to Calanus finmarchicus. Trans. Roy. Soc. Cahada, Vol. 12, 1918, pp. 207-233.

Dannevig, Alf. 1919. Canadian Fish-Eggs and Larvae. Canadian Fish. Exp. Invest. Gulf of St. Lawrence and Atl. waters of Canada, 1914-15 (1919), pp. 1-74, pl. 1-3.

Detweiler, John D. 1915. Preliminary notes on the mollusca of St. Andrews and vicinity, New Brunswick. Contr. Canadian Biol., 1911-14, Fasc. I. (1915), pp. 43-46.

1918. The pearly fresh-water Mussels of Ontario, with suggestions as to Culture and Utilization. Contr. Canadian Biol., 1917-18, pp. 73-91.

DUFF, Dorothy. 1916. Investigation of the haddock fishery, with special reference to the growth and maturity of the haddock. Contr. Canadian Biol., 1914-15, pp. 95-102.

Fowler, James. 1901. The flora of St. Andrews, New Brunswick. Contr. Canadian Biol., 1901, pp. 14-48. 
Fowler, James. 1907. Report on the flora of Canso, Nova Scotia. Contr. Canadian Biol., 1902-05, pp. 59-70.

Fraser, C. M. 1911. The Hydroids of the west coast of North America. Bull. Laboratories of Nat. Hist. State University of Iowa, pp. 1-91.

Includes distribution of material and sometimes descriptions of such, collected at the Pacific Station in 1908 and 1909 , as well as other material from Vancouver Island and Puget Sound.

1913. Hydroids from Vancouver Island. Ibid., pp. 147-155.

1913. Hydroids from Nova Scotia. Canadian Geol. Surv. Victoria Mem. Mus. Bull. 1, pt. XVI., pp. 157-186.

1914. Marine Biology in British Columbia. British Columbia Acad. Sci., pp. 49-60. Vancouver.

1914. Pacific Coast Biological Station, Departure Bay, B.C. Trans. Pacific Fisheries Soc., pp. 61-69.

1914. Some Hydroids of the Vancouver Island region. Trans. Roy. Soc. Canada, Ser. III., Vol. VIII., Section IV., pp. 99-216.

1914. Notes on some Alaskan hydroids. Ibid., pp. 217-222.

1915. The Swarming of Odontosyllis. Trans. Roy. Soc. Canada, Ser. III., Vol. IX., Section IV., pp. 43-49.

1915. Hydroids: in the Report of the Exploration of the coast water between Nova Scotia and Chesapeake Bay, July and August, 1913, by the United States Fisheries Schooner "Grampus." Bull. Mus. Comp. Zool. Harvard College, Vol. LIX., No. 4, pp. 306-314.

1916. On Chupea pallasii Cuvier and Valenciennes. Trans. Roy. Canadian Inst., pp. 97-108.

1916. Ichthyological Notes: I. Ophiodon elongatus Girard. II. Oncorhynchus keta Walbaum. III. The diagnosis of fish by means of scales. IV. Mallotus villosus Muller. Ibid., pp. 109-118.

1916. Possible lobster planting areas on the east coast of Vancouver Island, B.C. . Contr. Canadian Biol., 1914-1915, pp. 119-132.

1916. Growth of the spring salmon. Trans. Pacific Fisheries Soc. for 1915, pp. 29-35.

1916. On the development of Aequorea forskalea. Trans. Roy. Soc. Canada, Third Series, Vol. X., Section IV., pp. 97-104.

1917. On the Scales of the Spring Salmon. Contr. Canadian Biology for 1915, pp. 21-38.

1917. On the life-history of the Coho. Ibid., pp. 39-52.

1917. Grading of Pacific salmon. Pacific Fisherman, pp. 15-16.

1918. Monobrachium parasitum and other west coast Hydroids. Trans. Roy. Soc. Canada, Third Series, Vol. XII., Section IV., pp. 131-138.

1918. Hydroids of Eastern Canada. Contr. Canadian Biol., 1916-17, pp. 329-367.

1918. Rearing sockeye salmon in fresh water. Ibid., pp. 105-109.

1918. Migration of marine animals. Trans. Roy. Soc. Canada, Third Series, Vol. XII., Sect. IV., pp. 139-143. 
Fraser, C. M. 1920. Copepods parasitic on fish from Vancouver Island region. Trans. Roy. Soc. Canada, Ser. III., Vol. XIII. for 1919, Sect. V., pp. 45-67.

1920. Growth rate in the Pacific salmon. Ibid., pp. 163-226.

1920. Enemies of North Pacific fishes. Canadian Fisherman, pp. 113-115.

1921. Key to the Hydroids of Eastern Canada. Contr. Canadian Biol., 1918-20, pp. 137-180.

1921. Further studies on the growth rate in Pacific salmon. Contr. Canadian Biol., 1918-1920, pp. 7-27.

1921. Some apparent effects of severe weather on the marine organisms in the vicinity of Departure Bay, B.C., Ibid., pp. 29-33.

1921. Temperature and specific gravity variations in the surface waters of Departure Bay, B.C., Ibid., pp. 35-47.

1921. Association, Commensalism and Parasitism among marine animals in the strait of Georgia, Canadian Field Nat., Vol. XXV., pp. 48-50.

Fritz, Clara W. 1921. Plankton diatoms, their distribution and bathymetric range in St. Andrews waters. Contr. Canadian Biol., 1918-20, pp. 49-62.

1921. Experimental cultures of diatoms occurring near St. Andrews, N.B. Contr. Canadian Biol., 1918-20, pp. 63-68.

Gilbert, C. H. 1912. A new genus and species of Cottoid fish from Departure Bay, Vancouver Island, B.C. Contr. Canadian Biol., 1906-1910, pp. 215-16.

Gran, H. H. 1919. Quantitative investigations as to Phytoplankton and pelagic Protozoa in the Gulf of St. Lawrence and outside the same. Canadian Fish. Exp., 1914-15, Gulf of St. Lawrence, pp. 487-491.

Gross, LouIs. 1919. An investigation into the question of early putrefaction of eviscerated fish in which the gills have been left. Rep. Adv. Council Sci. and Indust. Research, No. 6, pp. 1-4.

1921. An investigation into the rate of putrefaction in the common food fish caught in and around Passamaquoddy Bay, N.B. Contr. Canadian Biol., 1918-20, pp. 99-102.

Haddon, Kathleen. 1912. Hersilia (Clausidium) vaǹcouverensis, n.s., Ann. and Mag. Nat. Hist., Ser. 8, Vol. X., pp. 84-86.

1912. Herpyllobius arcticus. Quart. Journ. Micr. Sci., Vol. 58, pp. 385-410.

A copepod parasitic on British Columbia polchaets.

Harrison, F. C. 1918. Report of examination of affected salmon from Miramichi Hatchery Pond, New Brunswick. Contr. Canadian Biol., 1917-18, pp. 147-168.

1918. Some observations on haddock and "Finnan Haddies" relating to the bacteriology of cured fish. Contr. Canadian Biol., 1917-18, pp. $177-180$.

Hickson, S. J. 1915. Some Alcyonatia and a Stylaster from the west coast of North America. Proc. Zool. Soc. London, pp. 541-557.

1917. West Coast corals. Bionomical Leaflets, McGill University, No. 6, pp. 21-24. 
HJort, Johan. 1919. Introduction to the Canadian Fisheries Expedition, 1914-15. Canadian Fish. Exped. Invest. Gulf of St. Lawrence and Atlantic waters of Canada, pp. i.-xv.

Huntsman, A. G. 1911. Ascidians from the Coasts of Canada. Trans' Canadian Inst., Vol. IX., pp. 111-148.

1912. Holosomatous Ascidians from the coast of Western Canada. Contr. Canadian Biol., 1906-1910, pp. 103-185.

1913. The Classification of the Styelidae. Zool. Anz., Bd. XLI., pp. 482501.

1913. On the origin of the ascidian mouth.' Proc. Roy. Soc., B, Vol. 86, pp. 454-459.

1913. Protostigmata in Ascidians. Proc. Roy. Soc., B., Vol. 86, pp. 440-453.

1915. A new Caprellid from the Bay of Fundy. Contr. Canadian Biol., 1911-14, Fasc. I., pp. 39-42, pl. 5, 6.

1915. The Fresh-water Malacostraca of Ontario. Contr. Canadian Biol., 1911-14, Fasc. II., pp. 145-163.

1918. The Growth of the Scales in Fishes. Trans. Roy. Canadian Inst., Vol. XII., Ser. III., pp. 63-103.

1918. The vertical distribution of certain intertidal animals. Trans. Roy. Soc. Canada, Ser. III., Vol. XII., 53-60.

1918. The effect of the tide on the distribution of the fishes of the Canadian Atlantic coast. Trans. Roy. Soc. Canada, Ser. III., Vol. XII., pp. 61-67.

1918. The scale method of calculating the rate of growth in fishes. Trans. Roy. Soc. Canada, Ser. III., Vol. XII., pp. 47-52.

1918. Our eastern flat-fishes. The Canadian Fisherman, Vol. V., pp. 788790.

1918. Fisheries research in the Gulf of St. Lawrence in 1917. The Canadian Fisherman, Vol. V., pp. 740-744.

1918. Histories of New Food Fishes, I. The Canadian Plaice. Bull. Biol. Board of Canada, No. 1, Toronto, 1918, pp. 1-32.

1918. Report on affected salmon in the Miramichi, river, New Brunswick. Contr. Canadian Biol., 1917-18, pp. 167-173.

1919. The Bait Question. Biol. Board of Canada, Leaflet, No. 3, pp. 1-4.

1919. Growth of the young herring (so-called sardines) of the Bay of Fundy. Canadian Fish. Exped., 1914-15, Gulf of St. Lawrence, pp. 165-171.

1919. Some quantitative and qualitative plankton studies of Eastern Canadian Plankton, Ibid., pp. 405-485.

1919. The Growth of Fishes. Trans. Amer. Fish. Soc., Vol. 49, pp. 19-23.

1920. Climates of our Atlantic waters. Trans. Amer. Fish. Soc., Vol. 50, pp. 326-333.

1921. Age-determination, growth and symmetry in the test of the ascidian Chelyosoma. Trans. Roy. Canadian Inst., Vol. XIII., No. 1, pp. 27-38. 
Huntsman, A. G. 1921. Eastern Canadian Plankton--The distribution of the Tomopteridae obtained during the Canadian Fisheries Expedition, 1914-15. Contr. Canadian Biol., 1918-20, pp. 85-91.

1921. Eastern Canadian Plankton. The distribution of floating Tunicates (Thaliacea) obtained during the Canadian Fisheries Expedition, 1914-15. Contr. Canadian Biol., 1918-20, pp. 93-97.

Huntsman, A. G. and Reid, M. E. 1921. The success of Reproduction in Sagitta elegans in the Bay of Fundy and the Gulf of St. Lawrence. Trans. Roy. Canadian Inst., Vol. XIII., pp. 99-112.

KilboRn, L. J. and Macleod, J. J. R. 1920. Observations on the glycogen content of certain invertebrates and fishes. Quart. Journ. Exper. Physiol., Vol. XII., No. 4, pp. 317-330.

Material from the Pacific Coast Station.

KindeE, E. M. 1918. The Ship Worm (Teredo navalis) on the Atlantic Coast of Canada. Contr. Canadian Biol., 1917-18, pp. 91-101.

Kindle, E. M. and Whittaker, E. J. 1918. Bathymetric check-list of marine invertebrates of eastern Canada, with an Index to Whiteaves' catalogue. Contr. Canadian Biol., 1917-18, pp. 228-294.

Klugh, A. B. 1909. The excretion of Sodium chloride by Spartina glabra alterniflora. Rhodora, Vol. XI., p. 237.

1910. Notes on the flora of the Nerepis Marsh, New Brunswick. Ottawa Naturalist, Vol. XXIV., pp. 121-122.

1912. Notes on the flora of the St. Croix valley and Passamaquoddy region, New Brunswick. Contr. Canadian Biol., 1906-10, pp. 265-276, pl. $27-29$.

1913. Notes on the Algae of the Georgian Bay. Rhodora, Vol. XV., pp. 88-92.

1913. Notes on the Plant Formations of the Georgian Bay. Ontario Nat. Sci. Bull., No. 8.

1915. Notes on the Aquatic Plants of the Georgian Bay. Contr. Canadian Biol., 1911-14, Fasc. II., pp. 219-220.

1917. The marine algae of the Passamaquoddy region. Contr. Canadian Biol., 1915-16, pp. 79-85, pl. 8 .

1921. A new genus and three new species of Algae from the Miramichi river, N.B. Contr. Canadian Biol., 1918-20, pp. 181-183.

Knight, A. P. 1901. The effects of polluted waters on fish-life. Contr. Canadian Biol., 1901, pp. 9-18.

- 1907. The effects of dynamite explosions upon fish-life. Contr. Canadian Biol., 1902-05, pp. 21-30.

1907. A further report upon the effects of sawdust on fish-life. Contr. Canadian Biol., 1902-05, pp. 37-54.

1907. Sawdust and Fish Life. Final Report. Contr. Canadian Biol., 1902-05, pp. 111-119.

1912. Fishery Bait experiments. A report on the comparative merits of different kinds of bait used in cod-fishing along the Gaspe peninsula.' Contr. Canadian Biol., 1910, pp. 23-32. 
KNIGHT, A. P. 1916. Lobster sanctuaries and hatching ponds. An investigation of the Long Beach Lobster Pond, Digby County, Nova Scotia, in 1914. Contr. Canadian Biol., 1914-15, pp. 41-54, pl. 2-7.

1917. Official Report upon Lobster Conservation in Canada. Suppl. 51st. Annl. Rept. Fish. Branch Dept. Nav. Ottawa. Ser., 1916-17, pp. 1-48.

1918. Official Report on Lobster Investigations, 1917, and methods of increasing the lobster supply in Canada. Ottawa, 1918, pp. 1-21.

1918. Lobster Investigations, Long Beach Pond, Nova Scotia, 1915. Contr. Canadian Biol., 1917-18, pp. 51-71.

1919. Official Report on Lobster Investigations in Canada for 1918. Ottawa 1919, pp. 1-35.

1921. Histology of the Flexor tendon in the crushing claw of the lobster. Contr. Canadian Biol., 1918-20, pp. 185-188.

LANG, R. S. and MAClEOD, J. J. R. 1920. Observations on the reducing substances in the circulating fluids of certain invertebrates and fish. Quart. Journ. Exper. Physiol., Vol. XII., No. 4, pp. 331-337. Material from the Pacific station.

LEA, EINAR. 1919. Report on the age and growth of the herring in Canadian waters. Canadian Fish. Exped., 1914-15, Gulf of St. Lawrence and Atlantic waters of Canada, pp. 75-164.

LEIM; A. H. 1921. A new species of Spirontocaris with notes on other species from the Atlantic coast. Trans. Roy. Canadian Inst., Vol. 13, pp. 133-145, pl. 2-6.

Macallum, A. B. 1903. On the inorganic composition of the Medusae Aurelia flavidula and Cyanea arctica. Journ. Physiol., Vol. XXIX., pp. 213-241.

1904. The Palaeochemistry of the Ocean in relation to Animal and Vegetable Protoplasm. Trans. Canadian Inst., Vol. VII., pp. 535-562. Also University of Toronto Studies, Physiological Series, No. 5.

1910. On the Inorganic Composition of the blood of Vertebrates and Invertebrates and its Origin. Proc. Roy. Soc. London, Vol. B 82, pp. 602-624.

1913. Acineta Tuberosa: A Study on the Action of Surface Tension in Determining the Distribution of Salts in Living Matter. Proc. Roy. Soc. London, Vol. B 86, pp. 527-550, 2 pls.

MacBride, E. W. 1912. Oyster Culture and the Clam. Fishery, Prince Edward Island. Contr. Canadian Biol., 1906-10, pp. 217-220.

MacClement, W. T. 1915. Preliminary Report on the Plants of the Georgian. Bay, a Contribution to the Biology of the Georgian Bay Waters. Contr. Canadian Biol., 1911-14, Fasc. II., pp. 201-211.

1917. Diatoms and Lobster rearing. Contr. Canadian Biol., 1915-16, pp. 11-20.

MacKay, A. H. 1907. The Diatomaceae of Canso Harbour, Nova Scotia. Contr. Canadian Biol., 1902-05, pp. 55-58. 
Martis, W. H. 1915. Some experiments on the freezing and thawing of live fish. Contr. Canadian Biol., 1911-14, Fasc. I., pp. 73-75.

Mavor, J. W. 1915. Studies on the sporozoa of the fishes of the St. Andrews region, New Brunswick. Contr. Canadian Biol., 1911-14, Fasc. I., pp. 25-38, pl. 4.

1915. On the Qccurrence of a Trypanoplasm, probably Trypanoplasma borreli Laveran and Mesnil in the Blood of the Common Sucker, Catostomus commersonii. Journ. Parasit., Vol. II., pp. 1-6.

1916. On the life-history of Ceratomyxa acadiensis, a new species of Myxosporidia from the eastern coast of Canada. Proc. Amer. Acad. Arts and Sci., Vol. LI., pp. 551-574.

1916. Studies on the Protozoan Parasites of the Fishes of the Georgian Bay. Trans. Roy. Soc. Canada, Ser. III., Vol. X., Sect. IV., pp. 63-73.

1918. On the age and growth of the pollock in the Bay of Fundy. Contr. Contr. Canadian Biol., 1917-18, pp. 107-125.

1920. Circulation of water in Bay of Fundy and Gulf of Maine. Trans. Amer. Fisher. Soc., Vol. L., pp. 334-342.

1920. Drift Bottles as indicating a superficial circulation in the Gulf of Maine. Science, N.S., Vol. LiII., p.p. 442-443.

1921. The utilization of Dog-Fish and selachian fishes of Eastern Canada. Contr. Canadian Biol., 1918-20, pp. 125-235.

1921. On a bottle which drifted from the Gulf of Maine to the Azores. Science, N.S., Vol. LIII., pp. 187-188.

1921. Another drift bottle which crossed the Atlantic. Science, N.S., Vol. LIII., p. 389.

Mavor, J. W., Craigie, E. H. and Detweiler, J. D. 1916. Investigation of the bays of the southern coast of New Brunswick, with a view to use for oyster culture. Contr. Canadian Biol., 1914-15, pp. 145149.

McDonald, D. L. 1912. On a collection of crustacea made at St. Andrews. Contr. Canadian Biology, 1906-10, pp. 83-84.

McMurrich, J. P. 1911. The Actiniaria of Passamaquoddy Bay with a discussion of their synonomy. Trans. Roy. Soc. Canada, Ser. III., Vol. IV., Sect. IV., pp. 59-83, pl. 1-3.

1912. The Life Cycles of the Pacific Coast Salmon belonging to the genus Oncorhynchus, as revealed by their scales and otolith markings. Trans. Roy. Soc. Canada, Ser. III., Vol. VI., Section IV., pp. 9-28.

1912. Observations on the Actiniarians occurring in the neighbourhood of the Biological Station, St. Andrews, New Brunswick. Contr. Canadian Biol., 1906-10, pp. 33-35.

1913. Some further observations on the life-histories of the Pacific Coast Salmon as revealed by their scale markings. Trans. Roy. Soc. Canada, Ser. III., Vol. VII., Section IV., pp. 23-32. Ottawa.

1913. Notes on the scale markings of the halibut and their bearing on questions connected with the Conservation of the fishery. Ibid., pp. $33-41$. 
McMurrich, J. P. 1913. Salmon fisheries of British Columbia. Commission of Conservation, Fourth Annual Report, pp. 48-59. Ottawa.

1913. On two new actinians from the coast of British Columbia. Proc. Zool. Soc. London, pp. 963-972.

1916. Notes on the Plankton of the British Columbia Coast. Trans. Roy. Soc. Canada, Ser. III., Vol. X., Section V., pp. 75-89.

1917. Notes on some crustacean forms occurring in the plankton of Passamaquoddy Bay. Trans. Roy. Soc. Canada, Ser. III., Vol. XI., Sect. IV., pp. 47-61.

1917. The winter plankton in the neighbourhood of St. Andrews, 1914-15. Contr. Canadian Biol., 1915-16, pp. 1-10.

Miller, F. R. 1910. Intestinal peristalsis and anal rhythm in Crustacea. Eighth Internat. Physiol. Congress, Vienna, 1910.

1910. On the rhythmical contractility of the anal musculature of the crayfish and lobster. Journ. Physiol., Vol. 40, p. 431.

1912. Contributions to the physiology of the American lobster. The physiology of the intestine. Contr. Canadian Biol., 1906-10, pp. 277-280, pl. 30-35.

Mórtensen, T. H. 1920. Studies on the development of crinoids. Papers from the Department of Marine Biology of the Carnegie Institute of Washington, Vol. XVI.

Florometra seratissima from the Pacific Coast station.

1921. Studies of the development and larval forms of Echinoderms, Copenhagen.

Strongylocentrotus drobachiensis, Pisaster ochracea, Evastterias trischelii, Orthasterias leptolena, Pycnopodia helianthoides, Stichopus californicus from British Columbia.

Nelson, Julius. 1917. An investigation of oyster propagation in Richmond Bay, P.E.I., during 1915. Contr. Canadian Biol., 1915-16, pp. 53-78.

Newcombe, C. F., Greenwood, W. H. and Fraser, C. M. 1918. The Sealion question in British Columbia. Contr. Canadian Biol., 1916-17, pp. 1-39.

O'Donoghue, C. H. 1921. Nudibranchiate Molluscs from the Vancouver Island region. Trans. Roy. Canadian Inst., Vol. XIII., No. 1, pp. 147-209.

Oldroyd, I. S. 1920. New species of West Coast shells. The Nautilus, Vol. XXXIII., No. 4, pp. 135-136.

Tritonalia fraseri from Departure Bay.

Patterson,.O. G. 1918. The smoking of haddocks for Canadian markets. Contr. Canadian Biol., 1917-18, pp. 173-178.

Penhallow, D. P. 1906. Report of a special committee on an examination of localities for the permanent location of the Marine Biological Station. Montreal, 1906, pp. 1-12.

1912. Report on the Atlantic Biological Station of Canada. Contr. Canadian Biol., 1906-10, pp. 1-21, pl. 1, 2. 
Pixell, H. L. M. 1912. Two new species of the Phoronidea from Vancouver Island. Quart. Journ. Microsc. Sci., Vol. 58, pt. 2, pp. 257-284.

1912. Polychaeta from the Pacific coast of North America, Part I. Serpulidae. Proc. Zool. Soc. London, pp. 784-805.

Much of the material was obtained at the Pacific Station.

Potrs, F. A. 1912. Mycetomorpha, a new Rhizocephalan. Zoolog. Jahrbucher, pp. 575-594.

1913. The swarming of Odontosyllis. Proc. Cambridge Philosoph. Soc, Vol. XVII., Part 2, pp. 193-200.

Observed in Departure Bay, B.C.

1913. Stolon formation in certain species of Trypanosyllis. Quart. Journ. Microsc. Sci., Vol. LVIII, Part 3, pp. 411-446.

Trypanosyllis gemmipara found at different points along the Vancouver Island coast.

1914. Polychaeta from the north-eastern Pacific. The Chaetopteridae. Proc. Zool. Soc. London, pp. 955-994.

Material from Pacific coast station.

Prince, E. E. 1901. Account of the Marine Biological Station of Canada; its foundation, equipment and work. Contr. Canadian Biol., 1901, pp. 1-8.

1907. The eggs and early life history of the Herring, Gaspereau, Shad and other clupeoids. Contr. Canadian Biol., 1902-05, pp. 95-110, pl. 8-10.

1907. Professor Macallum on the chemistry of Medusæ. Contr. Canadian Biol., 1902-05, pp. 121-128.

1913. A new Canadian Cirripede parasitic on a shrimp. Ottawa Naturalist, Vol. XXVI., No. 10, pp. 121-125.

From the Pacific coast station.

1913. The Biological Board of Canada. Reprint from the 4th Annl. Report Comm. Conservation, Ottawa, 1913, pp. 1-14.

1917. On serially striped haddock in New Brunswick. Contr. Canadian Biol., 1915-16, pp. 86-90, pl. 9.

1918. How to handle frozen fish. Bull. Coun. Sci. and Industr. Research, No. 3, Ottawa, 1918, pp. 1-4.

1918. Hints on frozen fish. Bull. Coun. Sci. and Industrial Research, No. 4, Ottawa, 1918, pp. 1-4.

Prince, E. E. and MacKay, A. H. 1901. The paired fins of the mackerel shark (Lamna). Contr. Canadian Biol., 1901, pp. 55-58, p1. 5-7.

Ramsay, L. N. E. 1914. On the Annelids of the family Nereidae collected by Mr. F. A. Potts in the north-east Pacific in 1911. Proc. Zool. Soc. London, pp. 237-250.

Nereis cyclurus, $\mathrm{N}$. virens, $\mathrm{N}$. agassizi, Micronereis variegata from vicinity of Pacific coast station.

Rathbun, M. J. 1917. The Grapsoid Crabs of America. United States Nat. Museum, Bulletin 97.

Includes references to material, particularly Pinnotherid material, collected at the Pacific coast station. 
Robertson, A. D. 1915. The Molluscs of the Georgian Bay. Contr. Canadian Biol., 1911-14, Fasc. II., pp. 96-111, 3 pls.

1916. Report on the barren oyster bottoms, Richmond Bay, P.E.I. ' Contr. Canadian Biol., 1914-15, pp. 55-71.

Robinson, C. B. 1907. The Seaweeds of Canso. Contr. Canadian Biol., 1902-05, pp. 71-74.

Ryerson, C. G. S. 1915. Notes on the Hirudinea of the Georgian. Bay. Contr. Canadian Biol., 1911-14, Fasc. II., pp. 165-175.

SADLER, WILfRID, 1918. The bacteriology of swelled canned sardines. Interim report. Contr. Canadian Biol., 1917-18, pp. 179-215.

1918. Bacterial destruction of Copepods occurring in marine plankton. Contr. Canadian Biol., 1917-18, pp. 215-228.

1921. Canned sardines-The cause of "Swells" or "Blown Cans." Contr. Canadian Biol., 1918-20, pp. 103-108.

Sandstrom, J. W. 1919. The Hydrodynamics of the Canadian Atlantic Waters. Canadian Fish. Exped., 1914-15, Gulf of St. Lawrence, pp. 221-343, 10 pls:

-Sars, G. O. 1915. The Entomostraca of the Georgian Bay. Contr. Canadian Biol., 1911-14, Fasc. II., pp. 221-222.

Scotr, F. H. 1901. The food of the Sea Urchin (Strongylocentrotus). Contr. Canadian Biol., 1901, pp. 49-54.

Stafford, J. 1901. The clam fishery of Passamaquoddy Bay, New Brunswick. Contr. Canadian Biol., 1901, pp. 19-40, pls. 1-4.

1904. Trematodes from Canadian Fishes. Zool. Anz. Bd. xxvii., pp. 481-495.

1905. Trematodes from Canadian Vertebrates. Zool. Anz. Bd. xxviii., pp. 681-694.

1905. On the larva and spat of the Canadian oyster. Amer. Nat., Vol. 39, pp. 41-44.

1907. On the fauna of the Atlantic coast of Canada. Contr. Canadian Biol., 1902-05, pp. 31-36.

1907. Preliminary report on the Trematodes of Canadian marine fishes. Contr. Canadian Biol., 1902-05, pp. 91-94.

1909. The larva and spat of the Canadian oyster. Amer. Nat., Vol. XLIII., pp. 31-47.

1910. The larva and spat of the Canadian oyster. Amer. Nat., Vol. XLIV., pp. 343-366.

1912. Supplementary observations on the development of the Canadian oyster. Amer. Nat., Vol. XLVI., pp. 29-40.

1912. On the fauna of the Atlantic coast. Second report (Malpeque, 1903-4). Contr. Canadian Biol., 1906-10, pp. 37-44.

1912. On the fauna of the Atlantic coast. Third report. Contr. Canadian Biol., 1906-10, pp. 45-67.

1912. On the fauna of the Atlantic Coast of Canada. Fourth report. Contr. Canadian Biol., 1906-10, pp. 69-78. 
StAFFoRd, J. 1912. On the recognition of bivalve molluscan larvae in plankton collections. Contr. Canadian Biol., 1906-10, pp. 221-242, pl. 22-24.

Stock, V. 1915. On some of the parasitic Copepods of the fishes of the Bay of Fundy. Contr. Canadian Biol., 1911-14, Fasc. I., pp. 69-71.

Stoner, D. 1920. Notes on Scutelleroidea from Vancouver Island. Canadian Entomologist, Vol. LI., pp. 12-13.

TAylor, G. W. 1912. Preliminary list of one hundred and twenty-nine species of B.C. Decapod Crustaceans. Contr. Canadian Biol., 1906-1910, pp. 187-214.

VACHON, A. 1917. Quelques problèmes de la mer. Bull. Soc. Geog. Quebec, Vol. XI.

1918. Hydrography in Passamaquoddy Bay and vicinity. Contr. Canadian Biol., 1917-18, pp. 294-325.

1920. L'Etoile de mer; son utilité comme engrais. Trans. Roy; Soc. Canada, Vol. XIV., Sect. V., pp. 39-49.

VanHorne, A and M. 1915. A list of fleshy fungi collected at St. Andrews and vicinity, New Brunswick. Contr. Canadian Biol., 1911-14 (1915), Fasc. I., pp. 47-50.

VerriLl, A. E. 1914. Monograph of the shallow water'starfishes of the North Pacific coast from the Arctic ocean to California. Smithsonian Institution, Harriman Alaska Expedition series, Vol. XIV.

Contains descriptions of many species, some of them new, collected near the station and at the other points along the coast of British Columbia.

Walker, E. M. 1914. The known nymphs of the Canadian species of Lestes (Odonata). Canadian Entomologist, Vol. XLVI., pp. 189-200.

1914. New and little known nymphs of Canadian Odonata. Ibid.; pp. $369-377$.

Aeshna tuberculifera, Ae. palmata, and Ae. umbrosa from Vancouver Island.

1914. New and little known nymphs of Canadian Odonata. Ibid.; pp. 349-357.

Ischnura cervula from Vancouver Island.

1915. Notes on the Odonata of the vicinity of Go Home Bay, Georgian Bay. Contr. Canadian Biol., 1911-14, Fasc. II., pp. 53-94, 7 pls.

1917. The known nymphs of the North American species of Sympetrum (Odonata). Canadian Entomologist, Vol. XLVIII., pp. 409-418.

S. vicinum, S. costiferum and S. pallipes from. Vancouver Island.

Wallace, N. A. 1910. The Isopoda of the Bay of Fundy. Univ. Toronto Stud., Bio. Ser., 1919, pp. 1-42.

White, H. T. 1915. Bryozoa of the Georgian Bay region. Contr. Canadian Biol., 1911-14, Fasc. II., pp. 195-199.

Willey, A. 1913. - Notes on plankton collected across the mouth of the St. Croix River opposite to the Biological Station at St. Andrews, New Brunswick, in July and August, 1912. Proc. Zool. Soc. London, 1913, pp. 283-292. 
1915. The plankton of St. Andrews Bay (New Brunswick). Contr. Canadian Biol., 1911-14, Fasc. I., pp. 1-9.

1916. Investigation into the Pacific Halibut Fisheries. Contr. Canadian Biol., 1914-15, pp. 1-18.

1919. Report on the Copepoda obtained in the Gulf of St. Lawrence and adjacent waters, 1915. Can. Fish. Exp. Invest. in the Gulf of St. Lawrence and Atlantic waters of Can., pp. 173-320.

1920. Marine Copepoda. Rept. Can. Arc. Exp., 1913-18. Vol. 7, Crustacea, Part K, pp. 1-46.

1920. The Economic History of Copepods. Trans. Amer. Fish. Soc., Vol. L., pp. 320-325.

1921. Arctic Copepoda in Passamaquoddy Bay. Proc. Amer. Acad. Arts and Sci., Vol. 56, No. 5, Boston, 1921, pp. 185-196.

Willey, A. and Huntsman, A. G. 1921. Faunal Notes from the Atlantic Biological Station. Canadian Field Nat., Vol. 35, pp. 1-7.

WILson; C. B. 1912. Parasitic Copèpods from Nanaimo, British Columbia, including eight species new to sciencè. Contr. Canadian Biol., 1906-1910, pp. 85-102.

1921. Argulidæ from the Shubenacadie River, Nova Scotia. Canadian Field Nat., Vol. 34, pp. 149-151.

Woodhouse, R. P. 1916. Report on the Life-history of the Cod, as determined from its scales and other data. Contr. Canadian Biol., 1914-16, pp. 103-113.

Wright, R. Ramsay. 1907. The Plankton of Eastern Nova Scotia waters. Contr. Canadian Biol., 1902-05, pp. 1-19, pl. 1-7. 